\title{
Content Analysis on Disaster Diplomacy Regime in Indonesia
}

\author{
Surwandono \\ International Relations Department \\ Universitas Muhammadiyah Yogyakarta \\ Yogyakarta, Indonesia \\ wsurwandono@yahoo.com
}

\author{
Ratih Herningtyas \\ International Relations Department \\ Universitas Muhammadiyah Yogyakarta \\ Yogyakarta, Indonesia \\ ratih_herningtyas@umy.ac.id
}

\begin{abstract}
This paper aims at analyzing some governmental regulations on disaster issues to understand government disaster diplomacy practices. Indonesia as a country that has significant levels of exposure to natural disaster. Unfortunetely, important government stakeholders on disaster issues are lack of understanding of how to conduct disaster diplomacy. Using content analysis toward three governmental regulations on disaster issues, this paper found that government stakeholders still have less understanding of disaster diplomacy. For one reason, the regulation on disaster management in Indonesia is not quite regulated conception of disaster diplomacy. Second, government regulation is less articulate how to construct and conduct disaster diplomacy as an important tool of disaster management.
\end{abstract}

Keywords-disaster diplomacy, disaster regulation, content analysis

\section{INTRODUCTION}

Indonesia is a prone-disaster nation since it is a meeting point of four big plates, namely Eurasian Plate, Australian Plate, the Philippine Sea Plate, and Pacific Plate. The active plates formed a volcanic chain from Sumatera, Java, Nusa Tenggara, Sulawesi, to Maluku. Volcanic and tectonic activities trigger natural hazards such as earthquakes, tsunami, and volcanic eruptions. According to a report of UN-ISDR (United Nations International Strategies for Disaster Reduction) entitled "The Asia Pacific Disaster report 2010", Indonesia possessed the second greatest number of dead, counted 191.164 dead, because of disaster in Asia Pacific for the recent twenty years [1]. It was also reported that financial loss was predicted about US\$ 22.5 billion. Besides, Bappenas mentioned that, in 2007, government spent US\$ 12 trillion as much as $3.1 \%$ of Indonesian PDB in 2007 or $15.8 \%$ of APBN in 2007. [2] As mentioned in the report, if massive disasters such as the 2004 Aceh earthquake and tsunami and the 2006 Yogyakarta earthquake recur, government will be economically overwhelmed.

Due to enormous impacts of disasters as mention above, urges government as the highest authority to take greater roles in disaster anticipation and management in Indonesia. Indeed, government entails measures of institutional frameworks of prevention, mitigation, responses, and systematic disaster reconstruction involving a number of national and international parties to cooperate technically and politically.

A contemporary study interestingly showed that natural disasters are not entirely considered negatively and destructively. A lot of lessons can be learned and occasions may emerge if disasters can be managed using an appropriate measure. In fact, the disasters can be capitalized in the form of disaster diplomacy.

Ilan Kelman contended that disaster diplomacy refers to a study of how and why disasters can contribute to and cannot contribute to peace or conflicts, examined in predisaster and post-disaster, and explained further that the disaster diplomacy discusses that the roles and activities of the disaster are in not only international relations but also political conflicts in an independent country [3], [4].

Andrew J. Snyder also mentioned that disaster diplomacy indisputably is very beneficial in international interaction because, when a disaster occurs, a state can notice policy of other countries on giving responses [5]. International relations also often stagnate in a policy response cycle, so that a disaster hitting a state will be assumed as a chance to commence a new cycle based on cooperation. Snyder argued that disaster diplomacy aims at escalating soft-power since the soft-power can be achieved as the result of the disaster diplomacy. The term of softpower coined by Joseph Nye refers to ability of a country to derive its interests without coercion or force [6]. A country opting soft power as the basis of diplomatic power relies on its ability to cooperate in gaining its goals. This diplomacy is believed more cost-efficiency than a "carrot and stick" strategy. A country providing a lot of aids in disaster management will be honored. This circumstance will indirectly lift a bargaining position of the country in international interaction. Mutually beneficial bilateral cooperation often emerges after the disaster diplomacy is undertaken. If a disaster occurs in conflict areas, various cooperation offer factors from political opponents will create peace. 
Indonesia has utilized disasters as a means of cooperation particularly in resolving conflicts and developing cooperation [7] Disaster diplomacy successfully undertaken by Indonesian government was a peace I. resolution in Aceh. Conflicts between GAM and Indonesia got better after Helinski peace agreement signing in August 2005 after the 2004 Aceh earthquake and tsunami. Both GAM and Indonesian government were aware that disaster management and recovery were the foremost priority so that a conducive situation of the conflict resolution was created. 180,000 dead and more than 500,000 people losing dwellings urged both parties to have a peace talk. Indeed, many members and sympathizers of GAM became victims of the earthquake and GAM military weakened due to Indonesian military offensives in 2003. International mediators also showed solidarity to monitor commitment of both parties to carry on peace negotiations. What to be noticed in the context is that efforts of conflict resolution had been undertaken before the earthquake, and it went more intensive and massive so that peace agreement could be coined rapidly.

In another case, in 2015 when Vanuatu was hit by cyclone pam, the worst disaster in Pacific, central government looked incapable of performing disaster diplomacy. Vanuatu was one of the countries acknowledged Free Papua Movement (OPM), and supporter of Melanesia solidarity. If it was well-managed, it would become an effective instrument to create Melanesian identity in Papua. However, Indonesian government went slowly utilizing the disaster to muffle Vanuatu to spread Melanesian solidarity. This paper aims at analyzing some governmental regulations on disaster issues to understand government disaster diplomacy practices. Indonesia as a country that has significant levels of exposure to natural disaster.

\section{FINDINGS AND DISCUSSION}

To conduct content analysis of Law No. 24/2007, PP No. 21/2008, and PP No. 23/2008, there are a number of significant phrases of disaster management to reveal whether research objects encompass, use, or manage diction A. of disaster diplomacy explicitly and implicitly. The next procedures were analyzing the three regulations and determining the number of important phrases having close meaning to disaster diplomacy in Indonesia. First, it is a phrase of disaster regulation objectives, whether the regulations powerfully describe disaster diplomacy practices. Second, it is a phrase of main actors of disaster management, whether the regulations strongly mention the involvement of international relations actors in disaster management. Third, it is actors' authority to manage policy in line with foreign actors. Fourth, it is a phrase of international cooperation scope in disaster management. Fifth, it is a phase of disaster management financing.

\section{A. Disaster Diplomacy Articulation}

To measure articulation of disaster diplomacy, researchers attempted to find out a number of explicit signs in disaster regulations representing indicators of disaster diplomacy. Disaster diplomacy simply refers to all domestic and international disaster events which lead to a number of disaster-related activities of politics, social, economy, and conflict. In the examined regulations, generally none of disaster regulations uses a term of disaster diplomacy. It showed that the concept of disaster diplomacy is a term which many regulation makers have not used and understood yet. This indicated an awareness problem that the concept of disaster diplomacy has never been recognized and comprehended by decision makes, and has not become an essential discourse to be included in a number of regulations or even in technical regulations dealing with international aid management.

B. Articulation of Disaster Management Objectives in Disaster Diplomacy Practices

To measure articulation of disaster management objective, researchers attempted to find out a number of explicit signs in disaster regulations representing indicators of disaster management objectives. In this context, disaster management objectives refer to a notion of Mark Pelling which categorized into three parts, namely mitigation, relief (emergency response), and recovery [8].

Disaster regulations of Indonesia generally emphasize of efforts of disaster prevention/mitigation that $44 \%$ of phrases showed disaster regulation, 39\% of phrases represented reconstruction-rehabilitation, and $16 \%$ of phrases indicated relief. In disaster diplomacy, three disaster issues are potential means to achieve national interests of a state. Mitigation, relief, and reconstruction issues refer to how to cooperate with international stakeholders to prepare regulation superstructures to cope with disaster risks, manage and rehabilitate disaster. Hence, an analysis of main actors in disaster management will obviously show whether or not the issues can be actualized.

C. Articulation of Main Actors of Disaster Management in Disaster Diplomacy Practices

Main actors of disaster management are classified into two parts, namely domestic or national actors and international actors. Domestic actors are both central and local government that the issue domains are foreign policy by central government and some of local government, and BNPB as a technical institution whose main duties and functions are regarding disasters, society, community organization, and business. Besides, international actors comprise of United Nations, other states, foreign non- 
governmental organizations, international institutions, and international community. Foreign non-governmental organizations in international relations study refer to international non-governmental organization (INGO), while international institutions are international governmental organization (IGO).

Main actors in a number of disaster regulations place domestic actors as the most managed actors, as either a subject or an object. In comparison with international actors, $87.8 \%$ are domestic actors and $12.25 \%$ are A. international actors. It shows that international actors are not quite sufficient in Indonesian disaster issues, whether international disaster issues do not exist, a disaster is assumed as a domestic issue embedded in sovereign issues, or Indonesian disaster policy is oriented to inward-looking.

In detail, the most managed domestic actors as a subject are governments counted $40 \%$, while society as object is counted $44 \%$. BNPB as a technical institution is calculated $7 \%$, and community organization as well as business are 3\%. It indicates that disaster issues in Indonesia are generally managed by government, and has not provide wide decentralization spaces to other stakeholders such as BNPB, social organization, and business.

Regarding international actors, United Nations contributes $7.4 \%$, other countries are $4 \%$, international organizations are $4 \%$, foreign non-governmental organizations are $3 \%$, and international community is $3 \%$. It tells that United Nations becomes the most trusted international organization to be a partner of disaster management. On the contrary, other countries contribute only a half of the United Nations position. Interestingly, the portion of international community counted $5.7 \%$ is greater than the portion of other countries, international organizations or international non-governmental organizations calculated 4\%. A greater position of international community than other actors except United Nations is because international community is a more mobile unit so that it should be noticed not to be the main cooperation partner.

Articulation of Actors' Authority in Disaster Diplomacy Practices Several main indicators employed to measure actors' authority are policy-making, emergency response, management, recovery, and evaluation. Policymaking encompasses authority of planning to technical policy-being made. Disaster management consists of relief activities during a disaster and monitoring activities. Besides, evaluation is dealing with authority of postdisaster.

Authority of policy making has a greater portion counted 36\% than authority of management and emergency response. Management is counted $34 \%$, and recovery and evaluation are calculated respectively $18 \%$ and $5 \%$. It implies that disaster management in Indonesia provides a lot of occasions to arrange a new notion which can be employed for better disaster management process. There is a big tendency that a disaster management concept would rather be oriented to inward-looking than establish outwardlooking disaster management which means being active to perform international cooperation to manage disaster in Indonesia or overseas.

E. Articulation of Cooperation in Disaster Diplomacy Practices

Measuring cooperation forms and cooperation in diplomacy disaster can be recognized with two big indicators, namely international cooperation forms by international covenants, and cooperation in covenant levels in national and international spaces.

The cooperation spaces will be established in a number of indicators such as cooperation in fields of providing aids, education, aid management, management, and the so-called most crucial international aid management from and to other countries. It is important to highlight how international aids in a disaster are managed, and whether transparency of humanitarian activities in disaster management exists. The more articulate the international aids, the stronger the disaster management as a disaster diplomacy instrument

Orientation of international aids mentioned in regulations tends to inward-looking instead of outwardlooking. It means that regulation standards in law on Indonesian participation in overseas disaster management have not existed yet.

\section{CONCLUSION}

Disaster diplomacy practices in Indonesia has been undertaken by the government. Nevertheless, in a formal legal context, a number of regulations on disaster do not articulate explicitly the concept of disaster diplomacy. Any definitions and varieties of disaster diplomacy are not employed in regulations such as law, government regulations, presidential decree, and head of BNPB regulations. The disaster diplomacy concept vagueness affects characteristics of disaster management in Indonesia which is more inward looking than outward looking.

It is indicated by a number of phrases of disaster diplomacy practices are not articulated significantly in several key words in line with objectives, actors, authority, international cooperation, and disaster financing. Objectives of disaster management tend to focus on mitigation by relying on national resource management, disaster management actors that tend to government and provide lack of spaces for international partners. International 
cooperation is also not articulated well since it would focus on internal capacity rather than create partnership with international organizations or community. In the management aspect, disaster financing tend to be based on regular budget instead of irregular budget.

It is recommended conducting judicial reviews on disaster regulations in Indonesia in order to yield progressive and productive disaster governance in disaster management.

\section{REFERENCES}

[1] ESCAP, The Asia Pacific Disaster Report. 2010. Protecting Development Gains, UN-ISDR, Bangkok.

[2] Bappenas, 2007. Hasil Analisa Sistem Penanggulangan Bencana, Bappenas, Jakarta.
[3] Kelman,I., 2007. 'Disaster diplomacy: Can tragedy help build bridges among countries?', UCAR Quarterly, Fall.

[4] Gaillard, J.C.,E. Clavé, \& I. Kelman. 2008. "Wave of peace? Tsunami disaster diplomacy in Aceh, Indonesia".Geoforum, vol. 39, no. 1

[5] Nye, Joseph. S.. 2008. The Power to Lead. Oxford University Press, New York.

[6] Snyder, A.J, 2008. Is There a Silver Lining? Long-term Changes in International Cooperation Levels After a Natural Disaster, The University of Georgia,

[7] Herningtyas, Ratih \& Surwandono, 2014. "Diplomasi Bencana sebagai Sarana Meningkatkan Kerjasama Internasional" dalam Jurnal Hubungan Internasional, Vol. 3 No.2/ Oktober

[8] Pelling, Mark, 2003. Natural Disasters and Development in a Globalizing World, London, Routledge. 